\title{
ANALISIS KESTABILAN LERENG BERDASARKAN NILAI SLOPE MASS RATING DI DESA SUKAMAJU, TENGGARONG SEBERANG, KUTAI KARTANEGARA, KALIMANTAN TIMUR
}

\author{
Muhammad Amin Syam ${ }^{1 *}$, Heryanto ${ }^{1}$, Tommy Trides ${ }^{2}$, Laurensius Pian Pasiakan $^{1}$, Dita Amalia ${ }^{1}$ \\ ${ }^{1}$ Teknik Geologi, Fakultas Teknik, Universitas Mulawarman, Samarinda, Indonesia. \\ ${ }^{2}$ Teknik Pertambangan, Fakultas Teknik, Universitas Mulawarman, Samarinda, Indonesia \\ *Penulis koresponden. Alamat email: muhaminsyam24@fft.unmul.ac.id
}

\begin{abstract}
Abstrak
Penelitian ini dilakukan untuk menganalisis kestabilan lereng berdasarkan nilai Slope Mass Rating lereng batuan pada desa Sukamaju, Tenggarong Seberang, Kutai Kartanegara. Slope Mass Rating adalah sistem klasifikasi massa batuan yang dirancang khusus untuk lereng batuan dengan menggabungkan nilai Rock Mass Rating dan penyesuaian terhadap arah orientasi kekar. Parameter yang digunakan dalam metode ini adalah nilai kuat tekan, Rock Quality Designation (RQD), spasi bidang kekar, kondisi bidang kekar, dan kondisi airtanah. Nilai kuat tekan batuan pembentuk lereng adalah 27.14 Mpa dengan bobot 4, nilai RQD sebesar $85 \%$ dengan bobot 17 , spasi kekar rata-rata $48 \mathrm{~cm}$ dengan bobot 10 , kondisi kekar akumulatif memiliki bobot 20 , kondisi airtanah dengan bobot 15 , arah orientasi lereng tidak menguntungkan dengan bobot -24 , dan lereng masih merupakan lereng alamiah dengan bobot 15. Dengan menjumlahkan setiap parameter, maka diperoleh nilai Slope Mass Rating (SMR) sebesar 57. Nilai ini bermakna bahwa kondisi batuan tergolong normal, stabil pada sebagian lereng, dan dapat terjadi longsoran berupa jatuhan batuan dari kekar dan longsoran baji.
\end{abstract}

Kata kunci: kestabilan lereng, slope mass rating, rock mass rating.

\begin{abstract}
This study is to analyze slope stability based on Slope Mass Rating in Sukamaju area, Tenggarong Seberang, Kutai Kartanegara. Slope Mass Rating is rock mass classification designed specially for rock slope by combining Rock Mass Rating value and adjustment to joint orientation direction. Parameters used in this method are Uniaxial Compressive Strength (UCS), Rock Quality Designation (RQD), joint distance, joint condition, dan groundwater condition. UCS value of the rock is 20 Mpa by weight 4, RQD value is $72 \%$ by weight 17 , average joint distance is about $2 \mathrm{~cm}$ by weight 20 , weight of accumulative joint condition is 20 , groundwater condition has weight 15 , slope orientation direction is unfavaurable by weight -24 , the slope is still natural and has weight 15 . By menjumlahkan all parameters, therefore obtained value of Slope Mass Rating (SMR) sebesar 57. This value means that the rock condition is normal, stable in partial slope, can occur failure, such as rock fall from the joint and wedge failure.
\end{abstract}

Key Words : slope stability, slope mass rating, rock mass rating 


\section{Pendahuluan}

Pada daerah dengan morfologi yang curam dengan banyak bidang-bidang diskontinuitas, longsoran batuan adalah salah satu bencana alam yang sering terjadi. Hal ini terjadi karena adanya bidang diskontinuitas tersebut merupakan bidang lemah pada massa batuan yang membentuk lereng. Bidang lemah tersebut umumnya berupa struktur geologi yaitu rekahan atau kekar dan patahan. Berdasarkan struktur geologi yang dominan terdapat pada batuan pembentuk lereng maka dapat ditentukan jenis longsoran batuan berpotensi terjadi pada lereng tersebut.

Sifat fisik dan mekanik dari batuan pada lereng sangat menentukan mudah tidaknya longsoran batuan itu terjadi. Selain itu, arah orientasi kekar atau diskontinuitas terhadap muka lereng juga dapat memperbesar ataukah mengurangi kecenderungan longsoran massa batuan.

Sebelum terjadinya longsoran batuan, maka perlu dilakukan upaya mitigasi untuk mencegah atau mengurangi risiko longsoran batuan. Salah satu upaya mitigasi awal yang dapat dilakukan adalah analisis kestabilan lereng batuan berdasarkan nilai Slope Mass Rating. Metode ini adalah penilaian potensi longsoran batuan yang menggabungkan analisis kualitatif dan kuantitatif didasari oleh metode Rock Mass Rating dan penyesuaian arah orientasi kekar sehingga menghasilkan penilaian kestabilan lereng yang lebih baik.

Metode Slope Mass Rating (SMR) telah lama digunakan sebagai alat untuk mengevaluasi kondisi kestabilan lereng batuan secara cepat (Kamutchat, et al, 2007).

\section{Klasifikasi Massa Batuan}

\section{Metode Rock Mass Rating (RMR)}

Dalam Fahmi (2007), metode ini sudah diakui dan sering digunakan dalam kegiatan geologi teknik. Metode RMR diperkenalkan oleh Bieniawski. Metode RMR ini memasukkan 5 parameter utama (Tabel 1), yaitu disajikan pada:

1. Kekuatan Batuan Utuh (Intact Rock) Kekuatan batuan utuh (intact rock) dalam RMR dinyatakan dengan Uniaxial Compressive Strength (UCS). UCS merupakan kekuatan dari batuan utuh yang diperoleh dari hasil uji kuat tekan uniaksial. Menurut Deere dan Miller (1966), nilai UCS juga dapat ditentukan dari JCS dapat diperoleh dari pengeplotan Schmidt Rebound Hammer.

\section{Rock Quality Designation (RQD)}

Parameter RQD diperoleh melalui pengamatan inti bor yang terambil, dengan mengabaikan inti bor yang memiliki panjang kurang dari $10 \mathrm{~cm}$ dan menunjukkan sisanya sebagai persentase terhadap panjang pemboran. Namun jika menggunakan sistem scanline. Terlebih dahulu harus ditentukan frekuensi diskontinuitas atau kekar. Frekuensi diskontinuitas/kekar merupakan perbandingan antara jumlah diskontinuitas dalam satu scanline dengan panjang scanline. Frekuensi diskontinuitas dihitung dengan rumus:

Frekuensi $(\lambda)=\frac{\sum \text { Diskontinuitas }}{\text { Panjang Scanline }}$

Setelah diketahui nilai frekuensi kekar atau diskontinuitas, nilai tersebut digunakan untuk menghitung RQD dengan rumus:

$$
R Q D=100 e^{-0.1 \lambda}(0.1 \lambda+1)
$$

3. Spasi Diskontinuitas/Kekar Spasi diskontinuitas merupakan jarak antara dua diskontinuitas yang berdekatan dalam satu scanline.

Spasi Kekar $=\frac{\text { Panjang Scanline }}{\sum \text { Diskontinuitas }}$ 
4. Kondisi Diskontinuitas/Kekar

Kondisi diskontinuitas ditentukan dari deskripsi tiap bidang diskontinuitas, berupa tingkat pelapukan, kekasaran permukaan bidang diskontinuitas, kemenerusan bidang kekar atau diskontinuitas, lebar bukaan, dan material pengisi bidang diskontinuitas.

5. Kondisi Airtanah

Keberadaan air ini akan mengurangi kuat geser antara kedua permukaan diskontinuitas. Bobot parameter airtanah dapat ditentukan dengan beberapa cara yaitu pengamatan langsung di lapangan dan menentukan kondisi umum air.

\section{Metode Slope Mass Rating (SMR)}

Romana (1985) dalam Endartyanto (2007) telah memodifikasi sistem klasifikasi RMR untuk menentukan kestabilan dengan menambahkan faktor penyesuaian arah orientasi lereng dan metoda eskavasi lereng. Parameter yang dibutuhkan untuk klasifikasi slope mass rating (SMR) adalah sebagai berikut:

1. Arah kemiringan (dip direction) dari permukaan lereng $(\alpha s)$

2. Arah kemiringan (dip direction) diskontinuitas $(\alpha \mathrm{j})$

3. Sudut kemiringan diskontinuitas $(\beta \mathrm{j})$ dan kemiringan lereng $(\beta s)$

Tabel 1. Klasifikasi RMR dan nilai pembobotannya (modifikasi dari Bieniawski, 1989)

\begin{tabular}{|c|c|c|c|c|c|c|c|c|c|}
\hline \multicolumn{3}{|c|}{ Parameter } & \multicolumn{7}{|c|}{ Jangkauan Nilai } \\
\hline \multirow{3}{*}{1} & \multirow{2}{*}{$\begin{array}{l}\text { Kekuatan } \\
\text { Batuan } \\
\text { Utuh }\end{array}$} & \multirow{2}{*}{$\begin{array}{c}\text { Indeks Poin Load } \\
\text { Uniaxial } \\
\text { Compressive }\end{array}$} & \multirow{2}{*}{$\begin{array}{l}>10 \mathrm{MPa} \\
>250 \mathrm{MPa}\end{array}$} & \multirow{2}{*}{$\begin{array}{c}4-10 \\
\mathrm{MPa} \\
100-250 \\
\mathrm{MPa}\end{array}$} & \multirow{2}{*}{$\begin{array}{c}2-4 \mathrm{MPa} \\
50-100 \\
\mathrm{MPa}\end{array}$} & \multirow{2}{*}{$\begin{array}{c}1-2 \mathrm{MPa} \\
25-50 \\
\mathrm{MPa}\end{array}$} & \multicolumn{3}{|c|}{$\begin{array}{c}\text { Tidak menggunakan } \\
\text { Point Load }\end{array}$} \\
\hline & & & & & & & $\begin{array}{l}5-25 \\
\mathrm{MPa}\end{array}$ & $\begin{array}{l}1-5 \\
\mathrm{MPa}\end{array}$ & $\begin{array}{c}<1 \\
\mathrm{MPa}\end{array}$ \\
\hline & & Bobot & 15 & 12 & 7 & 4 & 2 & 1 & 0 \\
\hline \multirow[t]{2}{*}{2} & \multicolumn{2}{|c|}{ Rock Quality Designation } & $\begin{array}{c}90- \\
100 \%\end{array}$ & $75-90 \%$ & $50-75 \%$ & $25-50 \%$ & \multicolumn{3}{|c|}{$<25 \%$} \\
\hline & \multicolumn{2}{|r|}{ Bobot } & 20 & 17 & 13 & 8 & \multicolumn{3}{|c|}{3} \\
\hline \multirow[t]{2}{*}{3} & \multicolumn{2}{|c|}{ Spasi Diskontinuitas/Kekar } & $>2 \mathrm{~m}$ & $0.6-2 \mathrm{~m}$ & $\begin{array}{c}0.2-0.6 \\
\mathrm{~m}\end{array}$ & $\begin{array}{c}0.06-0.2 \\
\mathrm{~m}\end{array}$ & \multicolumn{3}{|c|}{$<0.06 \mathrm{~m}$} \\
\hline & \multicolumn{2}{|r|}{ Bobot } & 20 & 15 & 10 & 8 & \multicolumn{3}{|c|}{0} \\
\hline \multirow[t]{2}{*}{4} & \multicolumn{2}{|c|}{$\begin{array}{l}\text { Kondisi Bidang } \\
\text { Diskontinuitas }\end{array}$} & $\begin{array}{l}\text { Sangat } \\
\text { kasar } \\
\text { dinding } \\
\text { segar } \\
\text { tidak } \\
\text { menerus } \\
\text { rapat }\end{array}$ & $\begin{array}{c}\text { Kasar } \\
\text { terbuka } \\
<1 \mathrm{~mm} \\
\text { dinding } \\
\text { sedikit } \\
\text { lapuk }\end{array}$ & $\begin{array}{l}\text { Sedikit } \\
\text { kasar } \\
\text { terbuka } \\
<1 \mathrm{~mm} \\
\text { dinding } \\
\text { sangat } \\
\text { lapuk }\end{array}$ & $\begin{array}{c}\text { Terisi } \\
\text { Tebal }<5 \\
\text { mm } \\
\text { terbuka } 1 \\
-5 \mathrm{~mm} \\
\text { menerus }\end{array}$ & \multicolumn{3}{|c|}{$\begin{array}{c}\text { Terisi materail lunak }>5 \\
\mathrm{~mm} \\
\text { Terbuka }>5 \mathrm{~mm} \\
\text { Menerus }\end{array}$} \\
\hline & \multicolumn{2}{|r|}{ Bobot } & 30 & 25 & 20 & 10 & \multicolumn{3}{|c|}{0} \\
\hline \multirow{4}{*}{5} & \multirow{3}{*}{$\begin{array}{l}\text { Kondisi } \\
\text { Airtanah }\end{array}$} & $\begin{array}{l}\text { Aliran per } 10 \mathrm{~m} \\
\text { panjang } \\
\text { terowongan }\end{array}$ & 0 & $<10$ & $25-10$ & $25-125$ & \multicolumn{3}{|c|}{$>125$} \\
\hline & & Tekanan Air & 0 & $<0.1$ & $0.1-0.2$ & $0.2-0.5$ & \multicolumn{3}{|c|}{$>0.5$} \\
\hline & & Kondisi Umum & Kering & Lembab & Berair & Basah & \multicolumn{3}{|c|}{ Mengalir } \\
\hline & \multicolumn{2}{|r|}{ Bobot } & 15 & 10 & 7 & 4 & \multicolumn{3}{|c|}{0} \\
\hline
\end{tabular}

Tabel 2. Nilai pembobotan untuk kekar (Romana, 1985 dalam Endartyanto, 2007)

\begin{tabular}{|c|c|c|c|c|c|c|}
\hline Kasus & Syarat & $\begin{array}{c}\text { Sangat } \\
\text { Baik }\end{array}$ & Baik & $\begin{array}{c}\text { Cukup } \\
\text { Baik }\end{array}$ & Buruk & $\begin{array}{l}\text { Sangat } \\
\text { Buruk }\end{array}$ \\
\hline $\mathrm{P}$ & $|\alpha j-\alpha s|$ & \multirow{2}{*}{$>30^{\circ}$} & \multirow{2}{*}{$30^{\circ}-20^{\circ}$} & \multirow{2}{*}{$20^{\circ}-10^{\circ}$} & \multirow{2}{*}{$10^{\circ}-5^{\circ}$} & \multirow{2}{*}{$<5^{\circ}$} \\
\hline $\mathrm{T}$ & $|\alpha j-\alpha s-180|$ & & & & & \\
\hline $\mathrm{P} / \mathrm{T}$ & F1 & 0.15 & 0.4 & 0.7 & 0.85 & 1 \\
\hline $\mathrm{P}$ & $|\beta \mathrm{j}|$ & $<20^{\circ}$ & $20^{\circ}-30^{\circ}$ & $30^{\circ}-35^{\circ}$ & $35^{\circ}-45^{\circ}$ & $>45^{\circ}$ \\
\hline $\mathrm{P}$ & F2 & 0.15 & 0.4 & 0.7 & 0.85 & 1 \\
\hline $\mathrm{T}$ & F2 & 1 & 1 & 1 & 1 & 1 \\
\hline $\mathrm{P}$ & $\beta \mathrm{j}-\beta \mathrm{s}$ & $>10^{\circ}$ & $10^{\circ}-0^{\circ}$ & $0^{\circ}$ & $0^{\circ}-\left(-10^{\circ}\right)$ & $<-10^{\circ}$ \\
\hline $\mathrm{T}$ & $\beta \mathrm{j}-\beta \mathrm{s}$ & $<110^{\circ}$ & $110^{\circ}-120^{\circ}$ & $>120^{\circ}$ & - & - \\
\hline $\mathrm{P} / \mathrm{T}$ & F3 & 0 & -6 & -25 & -50 & -60 \\
\hline
\end{tabular}


Analisis Kestabilan Lereng Bedasarkan Nilai Slope Mass Rating Di Desa Sukamaju ....

Tabel 3. Nilai pembobotan untuk metode eskavasi lereng (Romana, 1985 dalam Endartyanto, 2007)

\begin{tabular}{|c|c|c|c|c|c|}
\hline Metode & Alami & Presplitting & $\begin{array}{c}\text { Smooth } \\
\text { Blasting }\end{array}$ & $\begin{array}{c}\text { Blasting atau } \\
\text { Mechanical }\end{array}$ & $\begin{array}{c}\text { Deffecient } \\
\text { Blasting }\end{array}$ \\
\hline F4 & 15 & 10 & 8 & 0 & -8 \\
\hline
\end{tabular}

Tabel 4. Deskripsi setiap kelas SMR (Romana, 1985 dalam Endartyanto, 2007)

\begin{tabular}{|c|c|c|c|c|c|}
\hline SMR & $\mathbf{0 - 2 0}$ & $\mathbf{2 1 - 4 0}$ & $\mathbf{4 1 - 6 0}$ & $\mathbf{6 1 - 8 0}$ & $\mathbf{8 1}-\mathbf{1 0 0}$ \\
\hline Kelas & V & IV & III & II & I \\
\hline Deskripsi & Sangat buruk & Buruk & Normal & Baik & Sangat baik \\
\hline Kestabilan & $\begin{array}{c}\text { Sangat tidak } \\
\text { stabil }\end{array}$ & Tidak stabil & Stabil sebagian & Stabil & Sangat stabil \\
\hline Longsoran & Bidang & Bidang dan baji & Baji dan kekar & Blok batuan & Tidak ada \\
\hline Stabilisasi & Reekskavasi & Koreksi lereng & Sistematis & Okasional & Tidak ada \\
\hline
\end{tabular}

Nilai SMR diperoleh dengan menjumlahkan antara nilai RMR, nilai faktor penyesuaian orientasi kekar, dan metode eskavasi pada lereng tersebut:

$$
\mathrm{SMR}=\mathrm{RMR}+(\mathrm{F} 1 \times \mathrm{F} 2 \times \mathrm{F} 3)+\mathrm{F} 4
$$

Dengan $F 1$ adalah sudut antara $\alpha \mathrm{j}$ dan $\alpha \mathrm{s}$, F2 adalah tangensial sudut kemiringan $\beta \mathrm{j}$, F3 adalah sudut antara $\beta$ s dan $\beta \mathrm{j}, \mathrm{F} 4$ merupakan metode eskavasi lereng. Bobot pengaruh orientasi lereng, metode eskavasi lereng, dan deskripsi kelas SMR disajikan pada Tabel 2 , Tabel 3, dan Tabel 4 di atas.

\section{Metodologi Penelitian}

Data-data yang dibutuhkan dalam analisis kestabilan lereng menggunakan metode Slope Mass Rating diperoleh dari investigasi lapangan. Data kekuatan batuan utuh (UCS) yang diperoleh menggunakan nilai kekerasan batuan dari uji Schmidt Rebound Hammer yang kemudian diplot pada grafik hubungan antara JCS dan nilai kekerasan batuan.

Nilai RQD dihitung menggunakan metode scanline, seperti yang ditunjukkan pada persamaan 1 dan 2. Spasi kekar rata-rata diperoleh berdasarkan persamaan 3 . Sedangkan kondisi kekar, kondisi airtanah, dan arah orientasi lereng berdasarkan penilaian kualitatif di lapangan dan pengukuran strike dan dip bidang diskontinuitas/kekar. Nilai SMR dihitung berdasarkan persamaan 4, namun sebelumnya menghitung nilai RMR dengan cara menjumlahkan bobot setiap parameter.
Dari nilai SMR dapat dideskripsikan kondisi kestabilan lereng dan jenis longsoran batuan yang dapat terjadi. Lereng pada daerah studi dapat dilihat pada Lampiran 1.

\section{Hasil dan Pembahasan}

\section{Menghitung Nilai RMR}

Nilai RMR diperoleh dengan menjumlahkan bobot setiap parameter, seperti yang ditunjukkan pada Tabel 1 . Nilai dan bobot setiap parameter disajikan pada Lampiran 2 dan 3 yang dijelaskan sebagai barikut:

1. Kekuatan Batuan Utuh

Nilai UCS diperoleh dengan memplot nilai uji Schmidt Rebound Hammer. Maka, diperoleh nilai rata UCS untuk 49 bidang kekar adalah sebesar 27.14 MPa.

2. Rock Quality Designation (RQD)

Nilai ini dihitung menggunakan metode scanline dengan terlebih dahulu menghitung besar frekuensi kekar per satuan panjang dan didapatkan frekuensi kekar pada lereng adalah 6.84 kekar/meter. Nilai RQD massa batuan adalah $85 \%$.

3. Spasi Kekar

Kekar pada lereng terdapat 2 jenis joint set atau kekar berpasangan dengan arah orientasi yang dominan. Pada lereng tersebut diperoleh spasi rata-rata kekar adalah $0.48 \mathrm{~m}$. 
4. Kondisi Kekar

Kondisi kekar dibagi menjadi lima parameter, yaitu panjang kekar, kekasaran, lebar bukaan, isi bukaan, dan tingkat pelapukan. Panjang rata-rata kekar adalah $46.9 \mathrm{~cm}$, kondisi permukaan yang kasar, lebar bukaan rata-rata kekar sebesar $0.02 \mathrm{~cm}$, bukaan berisi besi oksida, dengan kondisi sedikit lapuk.

5. Kondisi Airtanah

Kondisi air pada lereng terbilang tidak ada atau masih dalam kondisi kering.

Dari nilai dan kondisi lereng di atas ditentukanlah bobotnya untuk menghitung nilia Rock Mass Rating (RMR). Bobot untuk parameter kekuatan batuan utuh sebesar 27.14 adalah 4. Bobot untuk nilai RQD $85 \%$ adalah 17. Spasi kekar sebesar $48 \mathrm{~cm}$ mempunyai bobot 10 . Bobot kondisi kekar adalah jumlah setiap parameter dan diperoleh bobot sebesar 20. Kondisi batuan kering atau tidak ada pengaruh airtanah memiliki bobot 15 . Sehingga bobot total atau nilai RMR adalah:

$$
\mathrm{RMR}=4+17+10+20+15=66
$$

Nilai ini bermakna bahwa kondisi massa batuan pada lereng tersebut masih tergolong baik.

\section{Menghitung Nilai SMR}

Nilai SMR adalah faktor penyesuaian terhadap arah orientasi lereng dan metode eskavasi yang digunakan pada nilai RMR. Arah kemiringan (dip direction) dan kemiringan lereng masing-masing $240^{\circ} / 30^{\circ}$. Arah kemiringan dan kemiringan utama kekar diperoleh dengan memplot data-data orientasi kekar pada aplikasi Dips 6.0 (Gambar 1). dan diperoleh orientasi kekar adalah $270^{\circ} / 13^{\circ}$. Dari arah kemiringan lereng dan kekar, jenis longsoran yang dapat terjadi adalah longsoran bidang. Dari kedua nilai orientasi kekar dan lereng diperoleh nilai da bobot, yaitu:

$$
\begin{aligned}
& \mathrm{F} 1=|\alpha \mathrm{j}-\alpha \mathrm{s}|=\left|270^{\circ}-240^{\circ}\right|=30^{\circ} » 0.4 \\
& \mathrm{~F} 2=|\beta \mathrm{j}|=\left|13^{\circ}\right|=13^{\circ} \gg 1 \\
& \mathrm{~F} 3=\beta \mathrm{j}-\beta \mathrm{s}=13^{\circ}-30^{\circ}=17^{\circ} \gg-60, \\
& \mathrm{~F} 4=15 \text { (lereng alamiah) }
\end{aligned}
$$

sehingga dapat dihitung nilai total Slope Mass Rating (SMR) adalah:

$$
\mathrm{SMR}=66+(0.4 \times 1 \times-60)+15=57
$$

Nilai ini bermakna bahwa kondisi massa batuan pada lereng tersebut normal, sebagian stabil, dan sebagian dapat terjadi longsoran dari kekar atau baji.

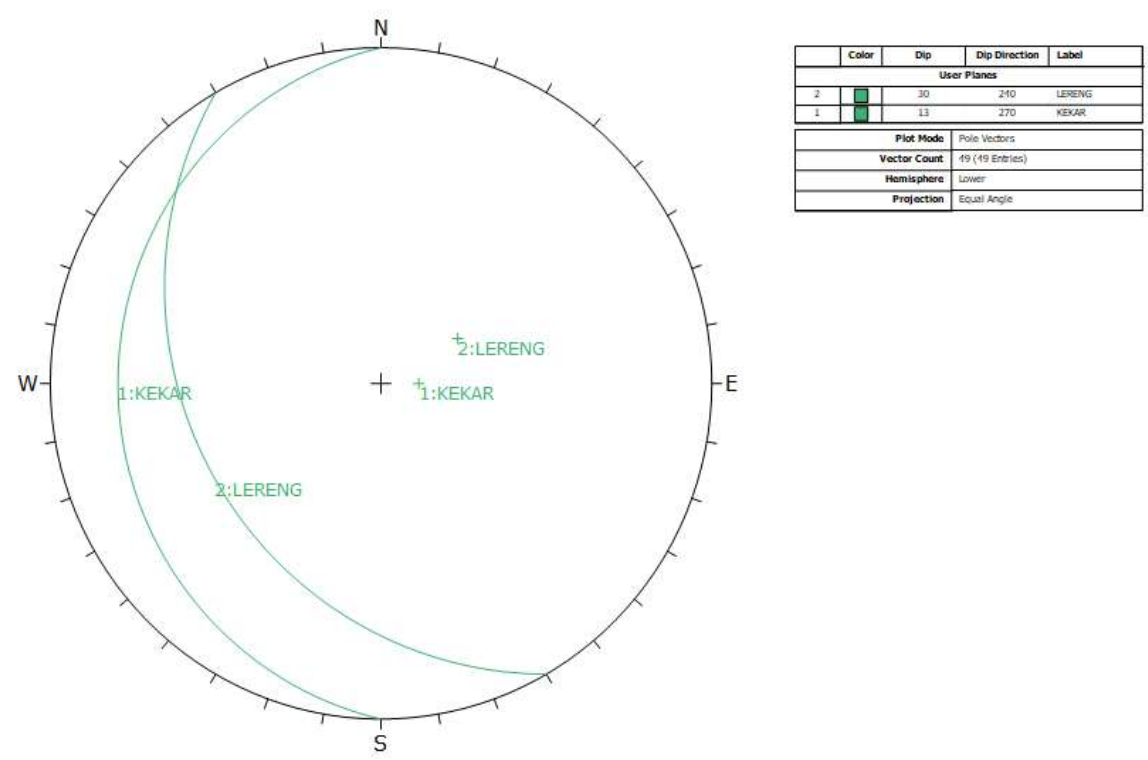

Gambar 1. Stereonet arah orientasi utama data kekar dan arah orientasi lereng 


\section{Kesimpulan}

Dari analisis kestabilan lereng menggunakan metode Slope Mass Rating (SMR), dapat disimpulkan bahwa:

1. Kualitas massa batuan berdasarkan nilai RMR dengan nilai total 66 tergolong kualitas batuan yang baik.

2. Analisis kestabilan lereng berdasarkan nilai SMR dengan nilai 57 tergolong lereng dengan kualitas massa batuan yang normal, stabil pada sebagian lereng, dan dapat terjadi longsoran berupa jatuhan batuan dari kekar dan longsoran baji.

\section{Daftar Pustaka}

Bieniawski, Z.T., 1989, Engineering Rock Mass Classification, John Wiley \& Sons, New York

Endartyanto, A., 2007, Analisis Kestabilan Lereng dengan Menggunakan
Metode Kinematik dan Klasifikasi Massa Batuan: Studi Kasus di Area Penambangan Andesit, Desa Jelekong, Kecamatan Bale Endah, Kabupaten Bandung, Jawa Barat, Teknik Geologi Institut Teknologi Bandung, Jawa Barat.

Fahmi, A., D., 2007, Analisis Kestabilan Lereng Batugamping dengan Menggunakan Metode Kinematik dan Klasifikasi Massa Batuan di Desa Nongkosepet, Kecamatan Ponjong Kabupaten Gunungkidul, Yogyakarta, Teknik Geologi Institut Teknologi Bandung, Jawa Barat

Kamutchat, S., Sri-in, T., Fuenkajorn, K., 2007, Verifications of Rock Slope Rating(RSR) and Slope Mass Rating (SMR) Systems, Rock Mechanics Journal, Fuenkajorn Fuenkajorn \& Phien-wej (eds), ISBN 978974533 6131 
Lampiran 1: Kondisi kekar pada lereng di daerah studi
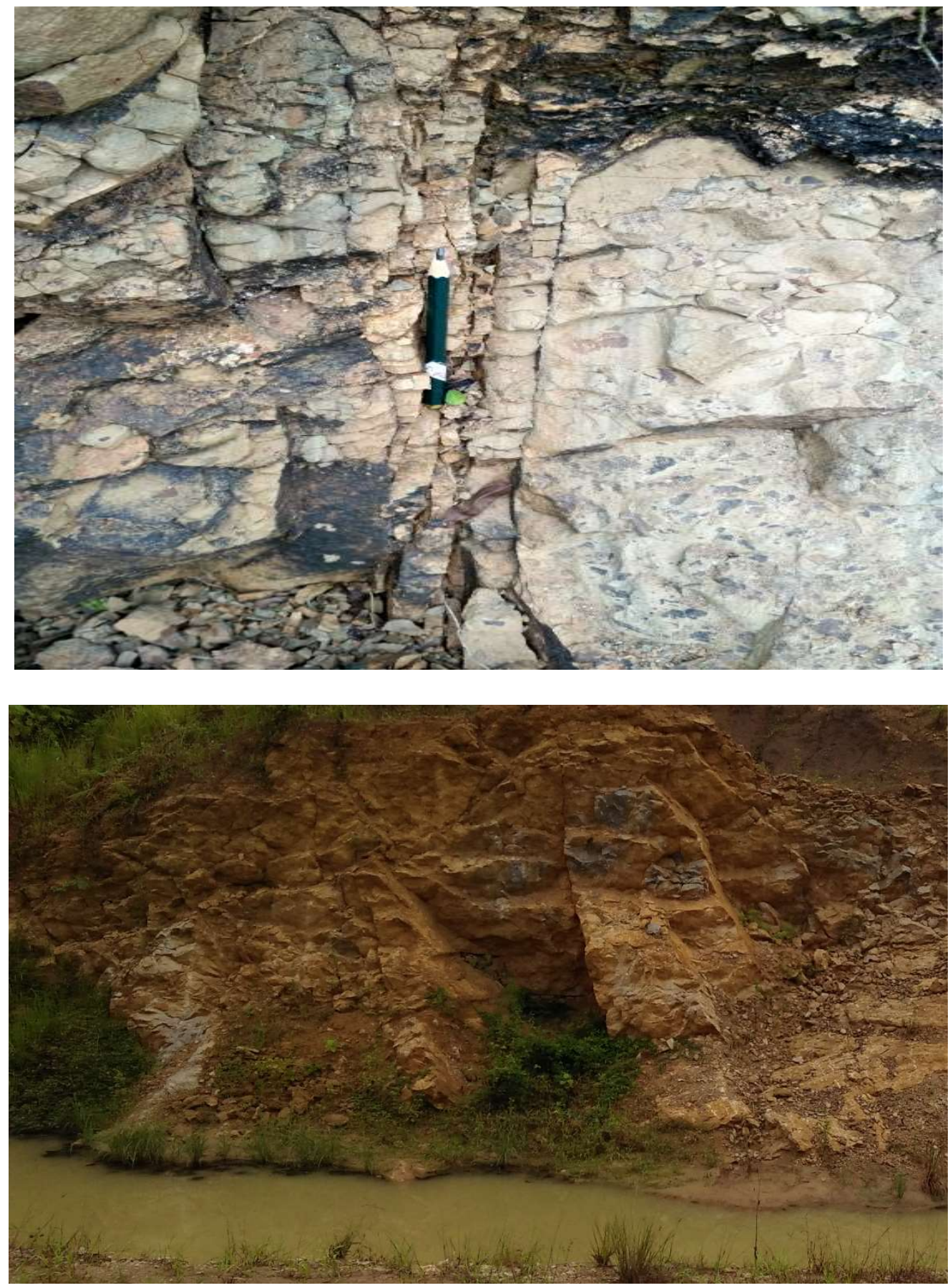
Analisis Kestabilan Lereng Bedasarkan Nilai Slope Mass Rating Di Desa Sukamaju ....

Lampiran 2: Perhitungan nilai RQD

\begin{tabular}{|c|c|c|c|c|c|c|c|c|c|c|c|c|c|c|c|c|c|}
\hline$\alpha f=$ & 240 & $\beta \mathrm{f}=$ & 30 & $\alpha \mathrm{s}=$ & 200 & $\beta \mathrm{s}=$ & 3 & & & & & & & & & & \\
\hline $\begin{array}{c}\text { Joint } \\
\text { Set }\end{array}$ & $\begin{array}{c}\text { Joint } \\
\text { No. }\end{array}$ & $\begin{array}{l}\mathrm{ad} \\
\left({ }^{\circ}\right)\end{array}$ & $\begin{array}{l}\text { bd } \\
\left(^{\circ}\right)\end{array}$ & $\begin{array}{c}\text { Jarak } \\
\text { Joint } / \\
\text { ji-m } \\
\text { (meter) }\end{array}$ & $\begin{array}{c}\text { an } \\
\text { ad }+ \\
180 \\
\left({ }^{\circ}\right)\end{array}$ & $\begin{array}{c}\text { bn } \\
90- \\
\text { bd } \\
\left({ }^{\circ}\right)\end{array}$ & $\begin{array}{c}\cos \\
\text { (an- } \\
\text { as) } \\
\left({ }^{\circ}\right)\end{array}$ & $\begin{array}{l}\text { cos } \\
\text { bn } \\
\left({ }^{\circ}\right)\end{array}$ & $\begin{array}{l}\cos \\
\text { bs } \\
\left({ }^{\circ}\right)\end{array}$ & $\begin{array}{l}\text { sin } \\
\text { bn } \\
\left(^{\circ}\right)\end{array}$ & $\begin{array}{l}\sin \\
\text { bs } \\
\left(^{\circ}\right)\end{array}$ & $\begin{array}{c}\text { abs } \\
{[\cos } \\
\Theta] \\
\left(^{\circ}\right)\end{array}$ & $\begin{array}{c}\text { Tetha } \\
(\Theta) \\
\left(^{\circ}\right) \\
\end{array}$ & \multicolumn{3}{|c|}{$\mathrm{i}-\mathrm{m}$} & \multirow[t]{2}{*}{$\begin{array}{l}\mathrm{d}(\mathrm{im}) \\
\text { (meter) }\end{array}$} \\
\hline A & 1 & 311 & 79 & 0.36 & & & & & & & & & & & & & \\
\hline A & 2 & 303 & 76 & 0.36 & 123 & 14 & 0.22 & 0.97 & 1.00 & 0.24 & 0.05 & 0.23 & 76.67 & 1 & - & 2 & 0.28 \\
\hline A & 3 & 340 & 66 & 0.42 & 160 & 24 & 0.77 & 0.91 & 1.00 & 0.41 & 0.05 & 0.72 & 43.93 & 2 & - & 3 & 0.21 \\
\hline A & 4 & 296 & 69 & 0.90 & 116 & 21 & 0.10 & 0.93 & 1.00 & 0.36 & 0.05 & 0.12 & 83.33 & 3 & - & 4 & 0.40 \\
\hline A & 5 & 298 & 11 & 0.30 & 118 & 79 & 0.14 & 0.19 & 1.00 & 0.98 & 0.05 & 0.08 & 85.53 & 4 & - & 5 & 0.03 \\
\hline A & 6 & 331 & 78 & 0.20 & 151 & 12 & 0.66 & 0.98 & 1.00 & 0.21 & 0.05 & 0.65 & 49.33 & 5 & - & 6 & 0.08 \\
\hline A & 7 & 356 & 58 & 0.35 & 176 & 32 & 0.91 & 0.85 & 1.00 & 0.53 & 0.05 & 0.80 & 36.74 & 6 & - & 7 & 0.26 \\
\hline A & 8 & 340 & 30 & 0.99 & 160 & 60 & 0.77 & 0.50 & 1.00 & 0.87 & 0.05 & 0.43 & 64.67 & 7 & - & 8 & 0.63 \\
\hline A & 9 & 235 & 67 & 0.10 & 55 & 23 & -0.82 & 0.92 & 1.00 & 0.39 & 0.05 & 0.73 & 42.90 & 8 & - & 9 & 0.06 \\
\hline A & 10 & 235 & 52 & 0.35 & 55 & 38 & -0.82 & 0.79 & 1.00 & 0.62 & 0.05 & 0.61 & 52.24 & 9 & - & 10 & 0.24 \\
\hline A & 11 & 309 & 60 & 0.60 & 129 & 30 & 0.33 & 0.87 & 1.00 & 0.50 & 0.05 & 0.31 & 72.08 & 10 & - & 11 & 0.28 \\
\hline A & 12 & 284 & 18 & 0.10 & 104 & 72 & -0.10 & 0.31 & 1.00 & 0.95 & 0.05 & 0.02 & 89.00 & 11 & - & 12 & 0.02 \\
\hline A & 13 & 310 & 48 & 0.93 & 130 & 42 & 0.34 & 0.74 & 1.00 & 0.67 & 0.05 & 0.29 & 73.21 & 12 & - & 13 & 0.14 \\
\hline A & 14 & 346 & 24 & 0.50 & 166 & 66 & 0.83 & 0.41 & 1.00 & 0.91 & 0.05 & 0.38 & 67.38 & 13 & - & 14 & 0.17 \\
\hline A & 15 & 294 & 42 & 0.40 & 114 & 48 & 0.07 & 0.67 & 1.00 & 0.74 & 0.05 & 0.09 & 85.09 & 14 & - & 15 & 0.10 \\
\hline A & 16 & 6 & 21 & 0.05 & 186 & 69 & 0.97 & 0.36 & 1.00 & 0.93 & 0.05 & 0.40 & 66.67 & 15 & - & 16 & 0.01 \\
\hline A & 17 & 315 & 76 & 0.47 & 135 & 14 & 0.42 & 0.97 & 1.00 & 0.24 & 0.05 & 0.42 & 65.03 & 16 & - & 17 & 0.19 \\
\hline A & 18 & 356 & 85 & 0.25 & 176 & 5 & 0.91 & 1.00 & 1.00 & 0.09 & 0.05 & 0.91 & 24.02 & 17 & - & 18 & 0.18 \\
\hline A & 19 & 348 & 71 & 0.48 & 168 & 19 & 0.85 & 0.95 & 1.00 & 0.33 & 0.05 & 0.82 & 35.14 & 18 & - & 19 & 0.42 \\
\hline A & 20 & 344 & 84 & 0.22 & 164 & 6 & 0.81 & 0.99 & 1.00 & 0.10 & 0.05 & 0.81 & 36.01 & 19 & - & 20 & 0.18 \\
\hline A & 21 & 320 & 68 & 2.38 & 140 & 22 & 0.50 & 0.93 & 1.00 & 0.37 & 0.05 & 0.48 & 61.15 & 20 & - & 21 & 1.57 \\
\hline A & 22 & 291 & 50 & 1.18 & 111 & 40 & 0.02 & 0.77 & 1.00 & 0.64 & 0.05 & 0.05 & 87.31 & 21 & - & 22 & 0.32 \\
\hline A & 23 & 278 & 50 & 0.24 & 98 & 40 & -0.21 & 0.77 & 1.00 & 0.64 & 0.05 & 0.13 & 82.80 & 22 & - & 23 & 0.02 \\
\hline A & 24 & 243 & 22 & 0.48 & 63 & 68 & -0.73 & 0.37 & 1.00 & 0.93 & 0.05 & 0.23 & 76.99 & 23 & - & 24 & 0.08 \\
\hline A & 25 & 295 & 25 & 0.46 & 115 & 65 & 0.09 & 0.42 & 1.00 & 0.91 & 0.05 & 0.08 & 85.17 & 24 & - & 25 & 0.07 \\
\hline A & 26 & 296 & 38 & 0.51 & 116 & 52 & 0.10 & 0.62 & 1.00 & 0.79 & 0.05 & 0.11 & 83.94 & 25 & - & 26 & 0.05 \\
\hline A & 27 & 328 & 85 & 0.59 & 148 & 5 & 0.62 & 1.00 & 1.00 & 0.09 & 0.05 & 0.62 & 51.90 & 26 & - & 27 & 0.22 \\
\hline A & 28 & 321 & 88 & 0.77 & 141 & 2 & 0.52 & 1.00 & 1.00 & 0.03 & 0.05 & 0.52 & 58.95 & 27 & - & 28 & 0.44 \\
\hline A & 29 & 330 & 82 & 0.12 & 150 & 8 & 0.64 & 0.99 & 1.00 & 0.14 & 0.05 & 0.64 & 49.99 & 28 & - & 29 & 0.07 \\
\hline A & 30 & 202 & 20 & 0.40 & 22 & 70 & -1.00 & 0.34 & 1.00 & 0.94 & 0.05 & 0.29 & 73.01 & 29 & - & 30 & 0.19 \\
\hline A & 31 & 358 & 76 & 0.12 & 178 & 14 & 0.93 & 0.97 & 1.00 & 0.24 & 0.05 & 0.91 & 24.35 & 30 & - & 31 & 0.08 \\
\hline A & 32 & 341 & 80 & 0.27 & 161 & 10 & 0.78 & 0.98 & 1.00 & 0.17 & 0.05 & 0.77 & 39.34 & 31 & - & 32 & 0.23 \\
\hline A & 33 & 335 & 25 & 0.56 & 155 & 65 & 0.71 & 0.42 & 1.00 & 0.91 & 0.05 & 0.35 & 69.77 & 32 & - & 33 & 0.32 \\
\hline A & 34 & 355 & 55 & 0.42 & 175 & 35 & 0.91 & 0.82 & 1.00 & 0.57 & 0.05 & 0.77 & 39.52 & 33 & - & 34 & 0.24 \\
\hline A & 35 & 350 & 35 & 0.20 & 170 & 55 & 0.87 & 0.57 & 1.00 & 0.82 & 0.05 & 0.54 & 57.39 & 34 & - & 35 & 0.13 \\
\hline
\end{tabular}


Syam, M.A., dkk/ Jurnal Geocelebes Vol. 2 No. 2, Oktober 2018, 53-63

\begin{tabular}{|c|c|c|c|c|c|c|c|c|c|c|c|c|c|c|c|c|c|}
\hline A & 36 & 334 & 55 & 0.53 & 154 & 35 & 0.69 & 0.82 & 1.00 & 0.57 & 0.05 & 0.60 & 53.25 & 35 & - & 36 & 0.30 \\
\hline A & 37 & 272 & 37 & 0.63 & 92 & 53 & -0.31 & 0.60 & 1.00 & 0.80 & 0.05 & 0.14 & 81.73 & 36 & - & 37 & 0.24 \\
\hline B & 38 & 260 & 75 & 0.23 & 80 & 15 & -0.50 & 0.97 & 1.00 & 0.26 & 0.05 & 0.47 & 62.05 & 1 & - & 2 & 0.20 \\
\hline B & 39 & 270 & 53 & 0.42 & 90 & 37 & -0.34 & 0.80 & 1.00 & 0.60 & 0.05 & 0.24 & 76.04 & 2 & - & 3 & 0.15 \\
\hline B & 40 & 115 & 35 & 1.42 & -65 & 55 & -0.09 & 0.57 & 1.00 & 0.82 & 0.05 & 0.01 & 89.60 & 3 & - & 4 & 0.18 \\
\hline B & 41 & 215 & 5 & 0.6 & 35 & 85 & -0.97 & 0.09 & 1.00 & 1.00 & 0.05 & 0.03 & 88.17 & 4 & - & 5 & 0.01 \\
\hline B & 42 & 205 & 23 & 0.3 & 385 & 67 & -1.00 & 0.39 & 1.00 & 0.92 & 0.05 & 0.34 & 70.09 & 5 & - & 6 & 0.06 \\
\hline B & 43 & 285 & 55 & 0.06 & 105 & 35 & -0.09 & 0.82 & 1.00 & 0.57 & 0.05 & 0.04 & 87.63 & 6 & - & 7 & 0.01 \\
\hline B & 44 & 255 & 20 & 1.05 & 75 & 70 & -0.57 & 0.34 & 1.00 & 0.94 & 0.05 & 0.15 & 81.56 & 7 & - & 8 & 0.10 \\
\hline B & 45 & 286 & 15 & 0.53 & 466 & 75 & -0.07 & 0.26 & 1.00 & 0.97 & 0.05 & 0.03 & 88.14 & 8 & - & 9 & 0.05 \\
\hline B & 46 & 252 & 10 & 0.29 & 432 & 80 & -0.62 & 0.17 & 1.00 & 0.98 & 0.05 & 0.06 & 86.83 & 9 & - & 10 & 0.01 \\
\hline B & 47 & 175 & 10 & 0.16 & 355 & 80 & -0.91 & 0.17 & 1.00 & 0.98 & 0.05 & 0.11 & 83.94 & 10 & - & 11 & 0.01 \\
\hline B & 48 & 250 & 8 & 0.16 & 70 & 82 & -0.64 & 0.14 & 1.00 & 0.99 & 0.05 & 0.04 & 87.85 & 11 & - & 12 & 0.01 \\
\hline B & 49 & 315 & 85 & 0.18 & 135 & 5 & 0.42 & 1.00 & 1.00 & 0.09 & 0.05 & 0.42 & 64.85 & 12 & - & 13 & 0.04 \\
\hline
\end{tabular}

$\begin{array}{ll}\text { Jarak rata-rata kekar A + B } & : 0.15 \\ \text { Frekuensi Kekar } & : 6.84 \text { kekar/meter } \\ \text { RQD } & : 85 \%\end{array}$


Lampiran 3: Penilaian kondisi kekar dan nilai UCS

\begin{tabular}{|c|c|c|c|c|c|c|c|c|c|c|}
\hline \multirow[b]{2}{*}{ 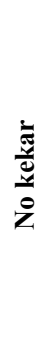 } & \multirow[b]{2}{*}{ 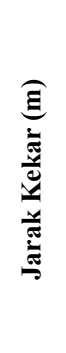 } & \multirow[b]{2}{*}{ 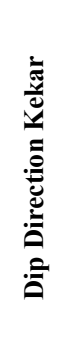 } & \multirow[b]{2}{*}{ 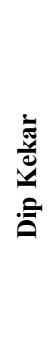 } & \multicolumn{7}{|c|}{ Kondisi kekar } \\
\hline & & & & 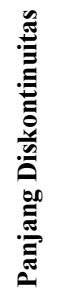 & 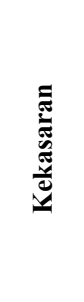 & 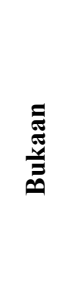 & 芴 & 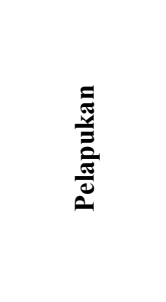 & 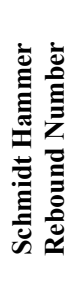 & 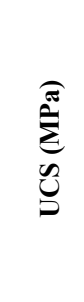 \\
\hline 1 & 0.36 & 311 & 79 & 39 & kasar & 0.02 & O.B & Sedikit lapuk & 3.2 & 31.392 \\
\hline 2 & 0.36 & 303 & 76 & 26 & kasar & 0.02 & O.B & Sedikit lapuk & 0.4 & 45.126 \\
\hline 3 & 0.42 & 340 & 66 & 34 & kasar & 0.02 & O.B & Sedikit lapuk & 4.1 & 47.088 \\
\hline 4 & 0.9 & 296 & 69 & 65 & kasar & 0.02 & O.B & Sedikit lapuk & 2.8 & 24.525 \\
\hline 5 & 0.3 & 298 & 11 & 42 & kasar & 0.02 & O.B & Sedikit lapuk & 1.5 & 36.297 \\
\hline 6 & 0.2 & 331 & 78 & 29 & kasar & 0.02 & O.B & Sedikit lapuk & 3.1 & 29.43 \\
\hline 7 & 0.35 & 356 & 58 & 65 & kasar & 0.02 & O.B & Sedikit lapuk & 3.2 & 23.544 \\
\hline 8 & 0.99 & 340 & 30 & 35 & kasar & 0.01 & O.B & Sedikit lapuk & 4.6 & 56.898 \\
\hline 9 & 0.1 & 235 & 67 & 12 & kasar & 0.01 & O.B & Sedikit lapuk & 2.16 & 15.696 \\
\hline 10 & 0.35 & 235 & 52 & 20 & kasar & 0.01 & O.B & Sedikit lapuk & 3.8 & 33.354 \\
\hline 11 & 0.6 & 309 & 60 & 72 & kasar & 0.02 & O.B & Sedikit lapuk & 2.8 & 24.525 \\
\hline 12 & 0.1 & 284 & 18 & 55 & kasar & 0.02 & O.B & Sedikit lapuk & 2.5 & 19.62 \\
\hline 13 & 0.93 & 310 & 48 & 59 & kasar & 0.02 & O.B & Sedikit lapuk & 3.5 & 36.97 \\
\hline 14 & 0.5 & 346 & 24 & 10 & kasar & 0.02 & O.B & Sedikit lapuk & 3.4 & 35.316 \\
\hline 15 & 0.4 & 294 & 42 & 21 & kasar & 0.01 & O.B & Sedikit lapuk & 3.3 & 33.354 \\
\hline 16 & 0.05 & 6 & 21 & 39 & kasar & 0.02 & O.B & Sedikit lapuk & 3 & 28.449 \\
\hline 17 & 0.47 & 315 & 76 & 75 & kasar & 0.02 & O.B & Sedikit lapuk & 3.6 & 38.259 \\
\hline 18 & 0.25 & 356 & 85 & 110 & kasar & 0.02 & O.B & Sedikit lapuk & 2.4 & 18.639 \\
\hline 19 & 0.48 & 348 & 71 & 142 & kasar & 0.01 & O.B & Sedikit lapuk & 4 & 45.126 \\
\hline 20 & 0.22 & 344 & 84 & 148 & kasar & 0.01 & O.B & Sedikit lapuk & 3.4 & 35.316 \\
\hline 21 & 2.38 & 320 & 68 & 48 & kasar & 0.01 & O.B & Sedikit lapuk & 4.2 & 49.05 \\
\hline 22 & 1.18 & 291 & 50 & 46 & kasar & 0.01 & O.B & Sedikit lapuk & 3 & 28.449 \\
\hline 23 & 0.24 & 278 & 50 & 27 & kasar & 0.01 & O.B & Sedikit lapuk & 1.8 & 9.81 \\
\hline 24 & 0.48 & 243 & 22 & 54 & kasar & 0.01 & O.B & Sedikit lapuk & 2.2 & 9.81 \\
\hline 25 & 0.46 & 295 & 25 & 52 & kasar & 0.01 & O.B & Sedikit lapuk & 2.8 & 24.525 \\
\hline 26 & 0.51 & 296 & 38 & 52 & kasar & 0.01 & O.B & Sedikit lapuk & 1.6 & 9.81 \\
\hline 27 & 0.59 & 328 & 85 & 84 & kasar & 0.01 & O.B & Sedikit lapuk & 5.6 & 68.67 \\
\hline 28 & 0.77 & 321 & 88 & 85 & kasar & 0.01 & O.B & Sedikit lapuk & 1.1 & 9.81 \\
\hline 29 & 0.12 & 330 & 82 & 57 & kasar & 0.02 & O.B & Sedikit lapuk & 2.1 & 13.374 \\
\hline 30 & 0.4 & 202 & 20 & 36 & kasar & 0.02 & O.B & Sedikit lapuk & 3.2 & 31.392 \\
\hline 31 & 0.12 & 358 & 76 & 46 & kasar & 0.01 & O.B & Sedikit lapuk & 1 & 9.81 \\
\hline 32 & 0.27 & 341 & 80 & 38 & kasar & 0.01 & O.B & Sedikit lapuk & 2.3 & 17.698 \\
\hline
\end{tabular}


Syam, M.A., dkk/ Jurnal Geocelebes Vol. 2 No. 2, Oktober 2018, 53-63

\begin{tabular}{|c|c|c|c|c|c|c|c|c|c|c|}
\hline 33 & 0.56 & 335 & 25 & 26 & kasar & 0.01 & O.B & Sedikit lapuk & 3 & 28.449 \\
\hline 34 & 0.42 & 355 & 55 & 53 & kasar & 0.01 & O.B & Sedikit lapuk & 3 & 28.449 \\
\hline 35 & 0.2 & 350 & 35 & 25 & kasar & 0.02 & O.B & Sedikit lapuk & 3.6 & 29.43 \\
\hline 36 & 0.53 & 334 & 55 & 46 & kasar & 0.02 & O.B & Sedikit lapuk & 3.8 & 41.202 \\
\hline 37 & 0.63 & 272 & 37 & 52 & kasar & 0.02 & O.B & Sedikit lapuk & 3.6 & 38.259 \\
\hline 38 & 0.23 & 260 & 75 & 32 & kasar & 0.02 & O.B & Sedikit lapuk & 2.2 & 15.696 \\
\hline 39 & 0.42 & 270 & 53 & 44 & kasar & 0.02 & O.B & Sedikit lapuk & 2.8 & 22.563 \\
\hline 40 & 1.42 & 115 & 35 & 20 & kasar & 0.02 & O.B & Sedikit lapuk & 2 & 12.753 \\
\hline 41 & 0.6 & 215 & 5 & 17 & kasar & 0.02 & O.B & Sedikit lapuk & 2.5 & 19.62 \\
\hline 42 & 0.3 & 205 & 23 & 22 & kasar & 0.02 & O.B & Sedikit lapuk & 1.1 & 9.81 \\
\hline 43 & 0.06 & 285 & 55 & 15 & kasar & 0.01 & O.B & Sedikit lapuk & 2.2 & 15.696 \\
\hline 44 & 1.05 & 255 & 20 & 34 & kasar & 0.01 & O.B & Sedikit lapuk & 2.8 & 22.563 \\
\hline 45 & 0.53 & 286 & 15 & 63 & kasar & 0.02 & O.B & Sedikit lapuk & 2.5 & 19.62 \\
\hline 46 & 0.29 & 252 & 10 & 38 & kasar & 0.02 & O.B & Sedikit lapuk & 3 & 28.449 \\
\hline 47 & 0.16 & 175 & 10 & 43 & kasar & 0.02 & O.B & Sedikit lapuk & 2.8 & 22.563 \\
\hline 48 & 0.16 & 250 & 8 & 20 & kasar & 0.01 & O.B & Sedikit lapuk & 2.7 & 23.544 \\
\hline 49 & 0.18 & 315 & 85 & 27 & kasar & 0.01 & O.B & Sedikit lapuk & 1 & 9.81 \\
\hline
\end{tabular}

